\title{
Metaplastic Carcinoma of the Breast: A Clinical Study of 7 Cases from Balochistan
}

\author{
Abdul Hameed Baloch ${ }^{*}$, Shakeela Daud ${ }^{2}$, Jameela Shuja ${ }^{3}$, Adeel Ahmad ${ }^{4}$, Fateh Ali ${ }^{3}$, \\ Mohammad Akram³, Dost Mohammad Baloch', Abdul Majeed Cheema', \\ Mohammad Iqbal7, Jamil Ahmad1 \\ ${ }^{1}$ Department of Biotechnology and Informatics, BUITEMS, Quetta, Pakistan \\ ${ }^{2}$ Center for Advanced Molecular Biology (CAMB), Lahore, Pakistan \\ ${ }^{3}$ CENAR, Quetta, Pakistan \\ ${ }^{4}$ Institute of Biochemistry and Biotechnology (IBBt), UVAS, Lahore, Pakistan \\ ${ }^{5}$ Lasbela University of Agriculture, Water and Marine Sciences, Balochistan \\ ${ }^{6}$ Institute of Molecular Biology and Biotechnology, The University of Lahore, Pakistan \\ ${ }^{7}$ Bolan Medical College/Hospital (BMC) Quetta \\ Email: " hameedbaloch77@yahoo.com
}

Received 27 April 2014; revised 25 May 2014; accepted 21 June 2014

Copyright (C) 2014 by authors and Scientific Research Publishing Inc.

This work is licensed under the Creative Commons Attribution International License (CC BY). http://creativecommons.org/licenses/by/4.0/

(c) (i) Open Access

\section{Abstract}

Metaplastic carcinomas of the breast are rare heterogenous neoplasms characterized by adenocarcinoma with dominant areas of spindle cells, squamous and/or other mesenchymal differentiation, that comprise of $<5 \%$ of all invasive breast cancers. Our objective in this study was to review the pathological features and clinical outcomes for metaplastic carcinoma of breast in breast cancer patients registered in CENAR (Center for Nuclear Medicines and Radiotherapy), Balochistan. Present study was performed on 7 patients affected with metaplastic carcinoma of breast, who were registered patients in CENAR. Informed consent was taken from the patients and BMI was calculated by measuring the height and weight of the patients. Available clinical history obtained by retrieving the patients file and a copy of biopsy report was also obtained from the file. Metaplastic carcinoma of breast was $4.11 \%$ of all 170 breast cancer cases registered in CENAR from 2010-2012. Mean age was 40 years ranging from 25 - 50 years. Four subtypes of metaplastic carcinoma of breast were reported in this study; DCIS component was present in one case and mean tumor size was $6.12 \mathrm{~cm}$ ranging from $3.5-10 \mathrm{~cm}$. Metaplastic carcinomas of breast are rare heterogenous neoplasm with different characteristics, demographics and tumor biology and accounts for almost $>\mathbf{5 \%}$ of all breast cancer cases.

\footnotetext{
${ }^{*}$ Corresponding author.
}

How to cite this paper: Baloch, A.H., Daud, S., Shuja, J., Ahmad, A., Ali, F., Akram, M., Baloch, D.M., Cheema, A.M., Iqbal, M. and Ahmad, J. (2014) Metaplastic Carcinoma of the Breast: A Clinical Study of 7 Cases from Balochistan. Advances in Breast Cancer Research, 3, 106-110. http://dx.doi.org/10.4236/abcr.2014.33016 


\section{Keywords}

\section{Breast Cancer, Metaplastic Carcinoma of Breast, CENAR, Balochistan, BMI, MBC}

\section{Introduction}

Breast tumors arise mostly from glandular epithelium but in some cases glandular epithelium differentiates into non glandular mesenchymal tissue through the process called metaplasia [1]. Metaplastic carcinomas of the breast are rare heterogenous neoplasms characterized by adenocarcinoma with dominant areas of spindle cells, squamous and/or other mesenchymal differentiation [2]-[4]. Metaplastic carcinomas comprises of $<5 \%$ of all invasive breast cancers [5]-[9], whereas some studies suggest that MBC (Metaplastic Carcinoma of Breast) accounts $<1 \%$ of all the cases of breast cancer [4] [10]. Another subgroup of metaplastic carcinoma called as carcinosarcoma is the most rare primary malignancies of the breast found in $<0.1 \%$ of the cases [9]. Metaplastic carcinoma pathologically and clinically differs from typical adenocarcinoma. In metaplastic carcinoma nodal involvement has been shown to be less common compared to typical breast adenocarcinomas, with an incidence ranging from $6 \%-26 \%$. In metaplastic carcinoma of breast, hormone receptor expression is uncommon with reported ERPR positivity in $0 \%-17 \%$ of cases [11]-[13]. Similarly in other studies it has also been shown that most of the MBC cases are triple negative with a worsen prognosis [14]-[20]. MBC presents a different clinical picture as compared to other invasive carcinomas of breast, the mass of the tumor grows rapidly [4] [21] [22]. Despite of a larger palpable mass the axillary lymph nodes less likely be invaded in the patients affected with MBC with a 6\% - 26\% of the cases [7] [11]-[13] [17] where as in other cases of breast cancer the involvement of axillary lymph nodes is greater than $50 \%$ [23].

Present study was performed on 7 patients with metaplastic carcinoma registered in CENAR between 20102012. Our aim in this study was to review the pathological features and clinical outcomes for metaplastic carcinoma of breast in patients registered in CENAR.

\section{Materials and Methods}

This study was conducted in Balochistan University of information Technology, Engineering and Management Sciences, Quetta and Center for Nuclear Medicine and Radiotherapy (CENAR), Quetta. The study was approved by the institutional Review Board of BUITEMS. All the cases of breast cancer affected with MBC type registered in CENAR from 2010-2012 were included. An informed consent was taken from all the patients who took part as volunteers in this study. The clinical features and outcomes of the disease were reviewed by studying the patients file. Body mass index (BMI) was calculated by measuring the height and weight of the patients. All the informations regarding the disease were obtained from the patients files. Following parameters were investigated in this study including patient's ethnicity, age, BMI, histological classification of the cancer, tumor size and grade, involvement of lymph nodes and ERPR and HER2/Neu receptor status by reviewing the pathological reports.

\section{Results}

Seven cases of metaplastic carcinoma of breast out of 170 breast cancer patients diagnosed between 2010 and 2012 registered in CENAR were reviewed, which was the $4.11 \%$ of all breast cancer registered cases in CENAR. All patients were female with mean age at diagnosis of 40 years ranging from 25 - 50 years. BMI of the patients was also calculated by taking their height and weight. There were three patients from Pashtoon ethnic group, two were Afghani, one was Punjabi and one from Hazara ethnic group. Out of seven patients, one was under weight, three were normal, one was overweight and two were obese. Four subtypes of metaplastic carcinoma of breast cancer were recorded in this study including adenosquamous carcinoma, monotonic spindle cell carcinoma, adenocarcinoma with spindle cell metaplasia and metaplastic carcinoma with osteoclast giant cells. All seven cases were diagnosed with IDC, and one case including with DCIS component. The mean tumor size was $6.12 \mathrm{~cm}$ ranging from $3.5-10 \mathrm{~cm}$. Other pathological and clinical features observed in individual cases were; nuclear pleomorphisms, hyperchromatism, abnormal mitotic figures, tubule formations, come do and cribriforms, 
fibrocystic changes including epithelial hyperplasia, adenosis, cystically dilated glands, apocrine metaplasia and microcalcification, stromal fibrosis and fibroadrenoma. The features found in the metaplastic carcinoma of breast in the case affected bilaterally were; Left Breast: Breast tissue with foreign body giant cell reaction, fat necrosis, chronic inflammation and fibrosis. 14/35 lymph nodes found positive for tumor metastasis. Right Breast: Breast tissue with ductal hyperplasia, cystic changes microcalcification and focal fibroadenoma. 6/50 lypmh nodes for tumor metastsis. Clinical features are shown in Table 1.

\section{Discussion}

Metaplastic carcinoma of breast is a rare, uncommon and heterogenous disease consisting of tumors admixed with epithelial and non-epithelial elements and constitute between 0.2 - 5 percent of all breast cancers [24] [25].

In current study we identified 7 breast cancer patients with metaplastic carcinoma which was the $4.11 \%$ of all the breast cancer cases registered in CENAR during the period of 2009-2012. Whereas Arce-Grijalval in their study proposed $0.6 \%$ cases of metaplastic carcinoma of breast out of all breast cancer cases registered in the Instituto National de Cancerologia from 1995-2005 [26]. Mean age of patients diagnosed with metaplastic carcinoma in our study was 40 years ranging from 25 - 50 years. In their study Arce-Grijalval the mean age of the patients of metaplastic carcinoma was 47.9 years ranging from 24 - 74. But in another study carried out by Brenner R.J. found the median age was 65.5 years ranging from 33 - 87 years and study conducted by Beatty J.D. reported the mean age 55 years ranging from 26 - 80 years [26] [27]. In current study we identified four subtypes of metaplastic carcinoma of breast including adenosquamous carcinoma, monotonic spindle cell carcinoma, adenocarcinoma with spindle cell metaplasia and metplastic carcinoma with osteoclast giant cell. Wargotz et al. in their series of studies described five subgroups of metaplastic carcinoma of breast including matrix-producing carcinoma, spindle cell carcinoma, carcinosarcoma, squamous cell carcinoma of ductal origin and metaplastic carcinoma with osteoclast giant cells [7] [11] [12] [28] [29]. Studies suggest that associated ductal carcinoma in situ might be present in 50\% of cases [6]. In our study the DCIS component was present in one case which was the $14.23 \%$ of all the cases with metaplastic carcinoma of breast. The mean tumor size was 6.12 $\mathrm{cm}$ ranging from $3.5-10 \mathrm{~cm}$ in current study. Most studies suggest a large palpable masses with metaplastic carcinoma of breast [30]. In a study carried out by Kurain and Al-Nafussi presents tumor sizes $2.2-10 \mathrm{~cm}$ [31]. Park et al., in their study reported mean tumor size $4.2 \mathrm{~cm}$ and similarly [32] and Kaufman et al., reported in their study the median tumor size was $4.8 \mathrm{~cm}$ ranging from $2.5-18 \mathrm{~cm}$ [22]. whereas smaller tumor sizes have also been reported with metaplastic carcinoma of breast but data are sparse. In a study carried out between 1976 and 1997, the median tumor size was reported $3.4 \mathrm{~cm}$ ranging from $0.5-0.7 \mathrm{~cm}$ [17]. In another study from Nottingham, England the mean tumor size was reported $1.6 \mathrm{~cm}$ ranging from $0.7-2.4 \mathrm{~cm}$ [33].

\section{Conclusion}

Metaplastic carcinomas of breast are rare heterogenous neoplasm with different characteristics, demographics and tumor biology and accounts for almost $>5 \%$ of all breast cancer cases.

Table 1. Clinical features of the patients diagnosed with metaplastic carcinoma of breast.

\begin{tabular}{|c|c|c|c|c|c|c|c|c|c|}
\hline Patient & Ethnicity & Age & BMI & Tumor Size & $\begin{array}{l}\text { Tumor } \\
\text { Grade }\end{array}$ & $\begin{array}{l}\text { Nodal } \\
\text { Status }\end{array}$ & DCIS & $\begin{array}{l}\text { ERPR } \\
\text { Status }\end{array}$ & Laterality \\
\hline 1 & Pashtoon & 25 & 17.78 & $7 \mathrm{~cm}$ & III & $2 / 8$ & - & ERPR+ & Left \\
\hline 2 & Pashtoon & 35 & 36.7 & $10 \mathrm{~cm}$ & III & $3 / 16$ & DCIS & ERPR- & Left \\
\hline 3 & Pashtoon & 40 & 31.25 & $6 \mathrm{~cm}$ & III & $1 / 8$ & - & $\begin{array}{c}\text { Tripple } \\
\text { negative }\end{array}$ & Left \\
\hline 4 & Afghani & 50 & 20.07 & $9 \mathrm{~cm}$ & III & $1 / 20$ & - & ERPR- & Right \\
\hline 5 & Afghani & 35 & 24 & $3.5 \mathrm{~cm}$ & II & $\begin{array}{c}14 / 35 \text { and } \\
6 / 50\end{array}$ & - & ERPR+ & Bilateral \\
\hline 6 & Panjabi & 40 & 23.17 & $4 \mathrm{~cm}$ & II & $3 / 27$ & - & ERPR+ & Left \\
\hline 7 & Hazara & 40 & 29 & $4 \mathrm{~cm}$ & III & $4 / 9$ & - & ERPR- & Left \\
\hline
\end{tabular}




\section{Acknowledgements}

We thank to all the patients who took part as volunteers in this study, Special thanks to Director CENAR and his team for their kind support.

\section{References}

[1] Brenner, R.J., Turner, R.R., Schiller, V., Arndt, R.D. and Giuliano, A. (1998) Metaplastic Carcinoma of the Breast: Report of Three Cases. Cancer, 82, 1082-1087. http://dx.doi.org/10.1002/(SICI)1097-0142(19980315)82:6<1082::AID-CNCR11>3.0.CO;2-2

[2] Rauf, F., Kiyani, N. and Bhurgri, Y. (2006) Metaplastic Carcinoma of Breast, an Intriguing Rarity. Asian Pacific Journal of Cancer Prevention, 7, 667-71.

[3] Pitts, W.C., Rajos, V.A., Gaffey, M.J., Rouse, R.V., Esteban, J., Frierson, H.F., Kempson, R.L. and Weiss, L.M. (1991) Carcinomas with Metaplasia and Sarcomas of the Breast. American Journal of Clinical Pathology, 95, 623-632

[4] Tavassoli, F.A. (1992) Classification of Metaplstic Carcinomas of the Breast. Annual Review of Pathology, 27, 89-119.

[5] Rosen, P.P. (1997) Rosen’s Breast Pathology. Lippencott-Raven Philadelphia, 375-395.

[6] Elston, C.W. and Ellis, I.O. Vol. 13. The Breast In: Systemic Pathology. 3rd Edition, Churchill Livingstone, Edinburugh, 1998, 323-328.

[7] Wargotz, E.S. and Norris, H.J. (1990) Metaplastic Carcinomas of the Breast: IV. Squamous Cell Carcinoma of Ductal Origin. Cancer, 65, 272-276. http://dx.doi.org/10.1002/1097-0142(19900115)65:2<272::AID-CNCR2820650215>3.0.CO;2-6

[8] Oberman, H.A. (1987) Metaplastic Carcinoma of the Breast. The American Journal of Surgical Pathology, 11, 918-929. http://dx.doi.org/10.1097/00000478-198712000-00002

[9] Feder, J.M., de Paredes, E.S., Hogge, J.P. and Wilken, J.J. (1999) Unusual Breast Lesions: Radiologic-Pathologic Correlation. Radio Graphics, 19, S11-S26. http://dx.doi.org/10.1148/radiographics.19.suppl_1.g99oc07s11

[10] Luini, A., Aguilar, M., Gatti, G., Fasani, R., Brito, J.A., Maisonneuve, P., Vento, A.R. and Viale, G. (2007) Metaplastic Carcinoma of the Breast, an Unusual Disease with Worse Prognosis: The Experience of the European Institute of Oncology and Review of the Literature. Breast Cancer Research and Treatment, 101, 349-353. http://dx.doi.org/10.1007/s10549-006-9301-1

[11] Wargotz, E.S. and Norris, H.J. (1989) Metaplastic Carcinomas of the Breast: I. Matrix-Producing Carcinoma. Human Pathology, 20, 628-635. http://dx.doi.org/10.1016/0046-8177(89)90149-4

[12] Wargotz, E.S. Deos, P.H. and Norris, H.J. (1989) Metaplastic Carcinomas of the Breast: II. Spindle Cell Carcinoma. Human Pathology, 20, 732-740. http://dx.doi.org/10.1016/0046-8177(89)90065-8

[13] Gutman, H., Pollock, R.E., Janjan, N.A. and Johnson, D.A. (1995) Biological Distributions and Therapeutic Implications of Sarcomatoid Metaplasia of Epithelial Carcinoma of the Breast. Journal of the American College of Surgeons, 180, 193-199.

[14] Al Sayed, A.D. El Weshi, A.N., Tulbah, A.M., Rahal, M.M. and Ezzat, A.A. (2006) Metaplastic Carcinoma of the Breast Clinical Presentation, Treatment Results and Prognostic Factors. Acta Oncologica, 45, 188-195. http://dx.doi.org/10.1080/02841860500513235

[15] Tse, G.M., Tan, P.H., Putti, T.C., Lui, P.C.W., Chaiwun, B. and Law, B.K.B. (2006) Metaplastic Carcinoma of the Breast: A Clinicopathological Review. Journal of Clinical Pathology, 59, 1079-1083. http://dx.doi.org/10.1136/jcp.2005.030536

[16] Weigelt, B., Kreike, B. and Reis-Filho, J.A. (2009) Metaplastic Breast Carcinomas Are Basal-Like Breast Cancers: A Genomic Profiling Analysis. Breast Cancer Research and Treatment, 117, 273-280. http://dx.doi.org/10.1007/s10549-008-0197-9

[17] Rayson, D., Adjei, A.A., Suman, V.J., Wold, L.E. and Ingle, J.N. (1999) Metaplastic Breast Cancer: Prognosis and Response to Systemic Therapy. Annals of Oncology, 10, 413-419. http://dx.doi.org/10.1023/A:1008329910362

[18] Bae, S.Y., Lee, S.K., Koo, M.Y., Hur, S.M., Choi, M.Y., Cho, D.H. Kim, S., Choe, J.H., Lee, J.E., Kim, J.H., Kim, J.S., Nam, S.J. and Yang, J.H. (2011) The Prognoses of Metaplastic Breast Cancer Patients Compared to Those of TripleNegative Breast Cancer Patients. Breast Cancer Research and Treatment, 126, 471-478. http://dx.doi.org/10.1007/s10549-011-1359-8

[19] Jung, S.Y., Kim, H.Y., Nam, B.H., Min, S.Y., Lee, S.J., Park, C., et al. (2000) Worse Prognosis of Metaplastic Breast Cancer Patients than Other Patients with Triple-Negative Breast Cancer. Breast Cancer Research and Treatment, 120, 627-637. http://dx.doi.org/10.1007/s10549-010-0780-8

[20] Okada, N., Hasebe, T., Iwasaki, M., Tamura, N., Akashi-Tanaka, S., Hojo, T., et al. (2010) Metaplastic Carcinoma of 
the Breast. Human Pathology, 41, 960-970. http://dx.doi.org/10.1016/j.humpath.2009.11.013

[21] Kaufman, M.W., Marti, J.R., Gallager, H.S. and Hoehn, J.L. (1984) Carcinoma of the Breast with Pseudosarcomatous Metaplasia. Cancer, 53, 1908-1917. http://dx.doi.org/10.1002/1097-0142(19840501)53:9<1908::AID-CNCR2820530917>3.0.CO;2-F

[22] Chao, T.C., Wang, C.S., Chen, S.C. and Chen, M.F. (1999) Metaplastic Carcinomas of the Breast. Journal of Surgical Oncology, 71, 220-225. http://dx.doi.org/10.1002/(SICI)1096-9098(199908)71:4<220::AID-JSO3>3.0.CO;2-L

[23] Carter, C.L., Allen, C. and Henson, D.E. (1969) Relation of Tumor Size, Lymph Node Status and Survival in 24,740 Breast Cancer Cases. Cancer, 63, 181-187. http://dx.doi.org/10.1002/1097-0142(19890101)63:1<181::AID-CNCR2820630129>3.0.CO;2-H

[24] Smith, D.M., Rongaus, V.A., Wehmann, T.W., Agarwal, P.J. and Classen, G.J. (1996) Metaplastic Breast Carcinoma. Journal of the American Osteopathic Association, 96, 419-421.

[25] Johnson, T.L. and Kini, S.R. (1996) Metaplastic Breast Carcinoma: A Cytohistologic and Clinical Study of 10 Cases. Diagnostic Cytopathology, 14, 226-232. http://dx.doi.org/10.1002/(SICI)1097-0339(199604)14:3<226::AID-DC6>3.0.CO;2-F

[26] Arce-Grijalva, V., Vela-Chávez, T., Pérez-Sánchez, V.M. and Ruvalcaba-Limón, E. (2007) Metaplastic Carcinoma of the Breast: A Clinical and Pathological Study of 40 Cases. BMC Cancer, 7, A6. http://dx.doi.org/10.1186/1471-2407-7-S1-A6

[27] Beatty, J.D., Atwood, M., Tickman, R. and Reiner, M. (2006) Metaplastic Breast Carcinoma-Clinical Significance. The American Journal of Surgery, 191, 657-664. http://dx.doi.org/10.1016/j.amjsurg.2006.01.038

[28] Wargotz, E.S. and Norris, H.J. (1989) Metaplastic Carcinomas of the Breast. Cancer, 64, 1490-1499. http://dx.doi.org/10.1002/1097-0142(19891001)64:7<1490::AID-CNCR2820640722>3.0.CO;2-L

[29] Wargotz, E.S. and Norris, H.J. (1990) Metaplastic Carcinomas of the Breast: V. Metaplastic Carcinoma with Osteoclastic Giant Cells. Human Pathology, 21, 1142-1150. http://dx.doi.org/10.1016/0046-8177(90)90151-T

[30] Gunhan-Bilgen, I., Memiş, A., Üstün, E.E., Zekioglu, O. and Özdemir, N. (2002) Metaplastic Carcinoma of the Breast: Clinical, Mammographic and Sonographic Findings with Histopathologic Correlation. American Journal of Roentgenology, 178, 1421-1425. http://dx.doi.org/10.2214/ajr.178.6.1781421

[31] Kurain, K.M. and Al-Nafussi, A. (2002) Sarcomatoid/Metaplastic Carcinoma of the Breast: A Clinicopathological Study of 12 Cases. Histopathology, 40, 58-64. http://dx.doi.org/10.1046/j.1365-2559.2002.01319.x

[32] Park, J.M, Han, B.K., Moon, W.K., Choe, Y.H., Ahn, S.H. and Gong, G. (2000) Metaplastic Carcinoma of the Breast: Mammographic and Sonographic Findings. Journal of Clinical Ultrasound, 28, 179-186. http://dx.doi.org/10.1002/(SICI)1097-0096(200005)28:4<179::AID-JCU5>3.0.CO;2-Y

[33] Denley, H., Pinder, S.E., Tan, P.H., Sim, C.S., Brown, R., Barker, T., Gearty, J., Elston, C.W. and Ellis, I.O. (2000) Metaplastic Carcinoma Arising within Complex Sclerosing Lesions: A Report of Five Cases. Histopathology, 36, 203209. http://dx.doi.org/10.1046/j.1365-2559.2000.00849.x 
Scientific Research Publishing (SCIRP) is one of the largest Open Access journal publishers. It is currently publishing more than 200 open access, online, peer-reviewed journals covering a wide range of academic disciplines. SCIRP serves the worldwide academic communities and contributes to the progress and application of science with its publication.

Other selected journals from SCIRP are listed as below. Submit your manuscript to us via either submit@scirp.org or Online Submission Portal.
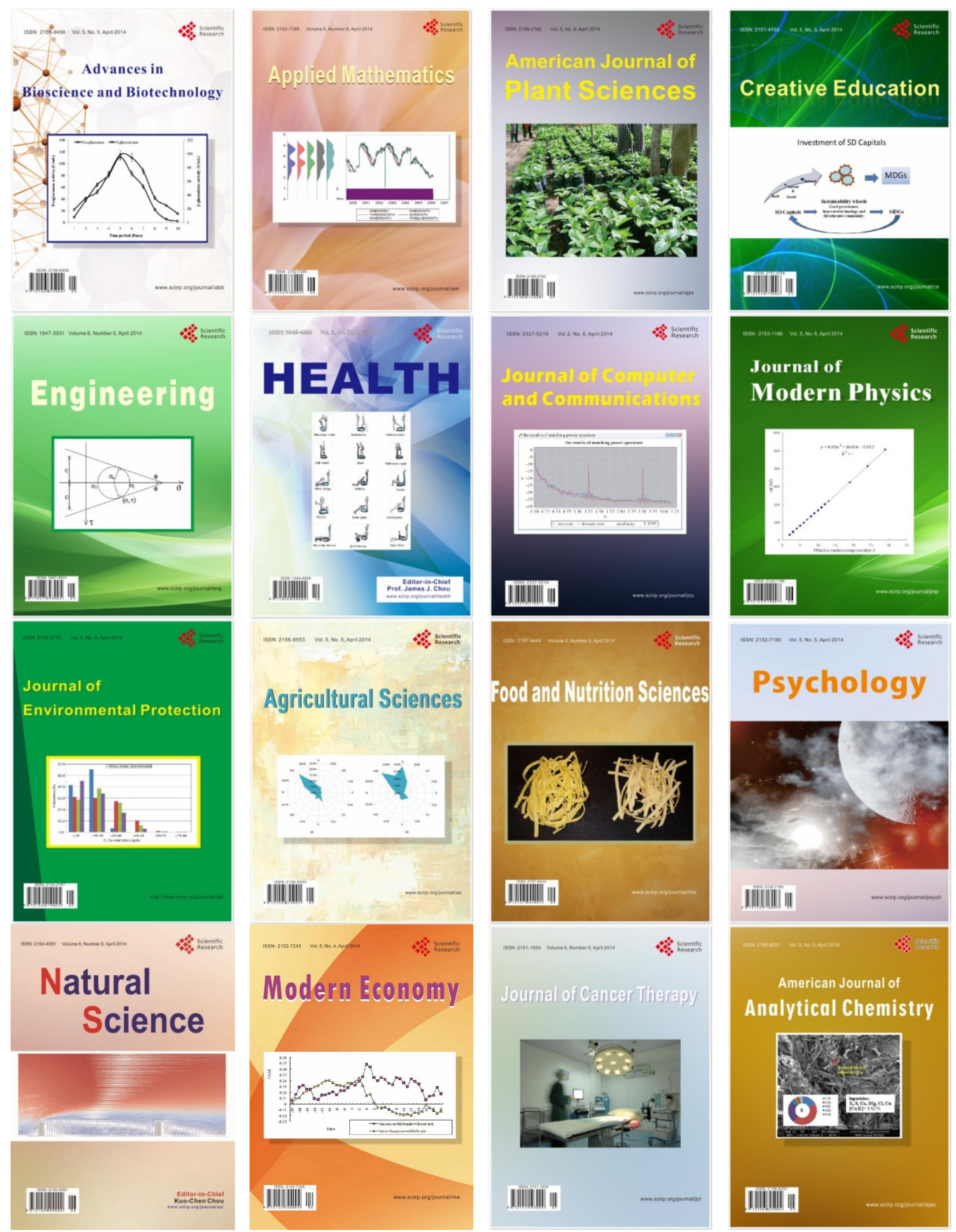